\title{
COMPARATIVE STUDY OF CHEMICAL COMPOSITION OF THE ESSENTIAL OILS FROM SATUREJA CUNEIFOLIA TEN. AND SATUREJA MONTANA L., LAMIACEAE COLLECTED AT NATIONAL PARK LOVĆEN, MONTENEGRO
}

\author{
DRAGICA BOJOVIĆa, MIOMIR ŠOŠKIĆb, VANJA TADIĆc,
}

\begin{abstract}
The main purpose of this study was an investigation of the chemical composition of essential oils obtained from Satureja cuneifolia Ten. and S. montana L. collected at the National park Lovćen, Montenegro. The qualitative and quantitative analysis of the essential oils, performed by GC/MS and GC/FID, indicated that the most abundant compound in $S$. cuneifolia essential oil was oxygenated monoterpene linalool (20.3\%). Within the sesquiterpene compounds, trans-(E)-caryophyllene $(6.1 \%)$, germacrene D $(5.8 \%)$, nerolidol $(5.2 \%)$ and spathulenol $(5.0 \%)$ were present in relatively high quantities. Conversely, S. montana essential oil was abundant in monoterpenes, with $p$-cymene being the main constituent (16.6\%). Besides, limonene (10.8\%), thymol $(6.5 \%)$, $\alpha$-pinene $(6.1 \%)$ and borneol $(5.5 \%)$ were present in a high percentage. The results indicated that investigated Satureja species essential oils possessed different chemical composition, but both might represent an interesting resource of pharmacologically active compounds.
\end{abstract}

Keywords: Satureja cuneifolia; Satureja montana; essential oil; terpenes; Montenegro.

\section{INTRODUCTION}

The medicinal plants of the genus Satureja (Lamiaceae family), commonly used herbs and shrubs, have been localised in the area of the Mediterranean region to Europe, Middle East, West Asia, North America

\footnotetext{
a Department of Pharmacy, Faculty of Medicine, Kruševac bb, 81000 Podgorica, Montenegro.

${ }^{b}$ Clinical Center of Montenegro, Ljubljanska bb, 81000 Podgorica, Montenegro.

c Institute for Medicinal Plant research "Dr Josif Pančić", Tadeuša Koščuška 1, 11000 Belgrade, Serbia.

*Corresponding author: vtadic@mocbilja.rs
} 
and Africa. As annual or perennial semi-bushy, these plants inhabit arid, stony, sunny and rocky habitats along the coast of the Adriatic Sea [1, 2, 3].

Satureja species have been traditionally used in the treatment of various diseases such as nausea, indigestion, cramps, diarrhoea, infectious diseases and muscle pains $[3,4]$. Up to now, numerous literature data stated that their essential oils possess antimicrobial activity against a wide range of multidrug-resistant pathogens [4]. In line with this statement, the essential oils obtained from S. cuneifolia and S. montana showed antimicrobial activity in vitro against various multidrug-resistant pathogens. The maximum activity of both essential oils was observed against methicillin-resistant Staphylococcus aureus and Gram (-) bacteria Escherichia coli. Both of these oils showed fungicidal activity against Candida albicans and Saccharomyces cerevisiae [5]. The considerable antibacterial and antifungal activities of essential oils from different Satureja species (S. boissieri, S. coerulea, S. icarica, $S$. pilosa and $S$. intermedia) also were documented in recently published papers $[6,7]$. Furthermore, the aqueous extracts of $S$. montana showed antiviral activities against HIV [8].

Several Satureja species have been well-studied and documented from various aspects of their secondary metabolites. It was found that these plants have glands on the leaf surface that produce and secrete essential oils, like other aromatic plants belonging to the mint family. As documented in recently published literature, essential oil obtained from $S$. montana ssp. montana consisted mainly of linalool, borneol and $p$-cymene, while that from $S$. montana ssp. variegata contained monoterpene phenols such as carvacrol and thymol as dominant compounds. S. cuneifolia essential oils are rich in limonene, linalool, $\alpha$-pinene, $\beta$-cubebene, $\gamma$-terpinene and carvacrol [9].

Different extraction methods might be employed in order to obtain volatile extracts and essential oils from $S$. montana and $S$. cuneifolia, conventional extraction techniques (hydrodistillation, HD, and Soxhlet extraction, SE) being mostly used [4, 10,11, 12]. But, these methods have been recognosed to possess many disadvantages, such as a longer period of extraction, less extraction efficiency and solvent residues in the obtained extracts. Non-conventional extractions methods (supercritical fluid extraction, SFE and supercritical water extraction, SWE) might be considered the better option for obtaining the high quality and high active extracts [10,13].

In our study, the analysis of essential oils obtained from two Satureja species, S. cuneifolia Ten. (wild savory) and S. montana L. (winter savory) were investigated in order to compare their chemical composition, taking into account that traditionally both species and their essential oils had application in the treatment of different health impairments. Winter savory honey is a very frequent ingredient in folk remedies known for their 
beneficial effects in the treatment of bronchitis. In addition, it is used as an antiseptic in gastrointestinal complaints, might be used as choleretic, digestive remedy, and in the treatment of premature ejaculation [14]. Wild savory is a medicinal and aromatic plant which essential oil commonly has application in the preparation of the aromatic water, especially in the mountainous areas of Turkey and in the Mediterranean region. In addition, this plant has application as a spice and tea due to its carminative, tonic and stimulant effects [15]. The presence of phenolic compounds in these plants' essential oil might be responsible for their taste and fragrance. Winter savory has been known for its antimicrobial activity, probably due to the presence of monoterpene, alcohols and phenolic compounds, as stated in available literature data [14, 15]. The use of wild savory in the Montenegro has been less frequent in comparison to above-mentioned areas where traditionally this plant has been well recognised.

The objective of the present study was to investigate the chemical composition of essential oils of two Satureja species, S. cuneifolia and S. montana collected from different locations at National park Lovćen in the south-western part of Montenegro. Further, the evaluated difference in their chemical composition was discussed in order to compare the obtained results to the data revealed in up-to-now literature regarding these two Satureja species' essential oils chemistry profile. The presented results might be of importance for the direction of further biological investigations.

\section{RESULTS AND DISCUSSION}

The obtained essential oils from dried aerial parts of $S$. cuneifolia and $S$. montana were yellow liquids. The yields of essential oils amounted to 0.2 and $0.9 \%(\mathrm{v} / \mathrm{w})$, respectively. Identification of chemical composition of the essential oil was performed using the gas chromatographic techniques. Based on applied techniques, more than 100 compounds were identified in both investigated essential oils, which made $98.6-98.9 \%$ of the total chemical compounds (Table 1).

GC chromatograms of analysed essential oils and representative examples of MS spectra of compounds identified in both of analysed essential oils were presented at figures 1 - 3 . 
Table 1. Phytochemical analysis of essential oil profiles of $S$. cuneifolia and S. montana

\begin{tabular}{|c|c|c|c|c|c|}
\hline $\mathbf{N}^{0}$ & Compound $\S$ & RT & $\mathbf{K} I^{\mathrm{a}} / \mathrm{KI}^{\mathrm{b}}$ & \begin{tabular}{|c|} 
S. cuneifolia \\
$(\%)$
\end{tabular} & $\begin{array}{c}\text { S. montana } \\
(\%)\end{array}$ \\
\hline 1. & tricyclene & 6.45 & $921 / 912$ & - & 0.3 \\
\hline 2. & $\alpha$-thujene & 6.62 & $924 / 918$ & - & 0.2 \\
\hline 3. & $\alpha$-pinene & 6.70 & $932 / 923$ & 0.7 & 6.1 \\
\hline 4. & camphene & 7.13 & $946 / 937$ & 0.2 & 4.5 \\
\hline 5. & thuja-2,4(10)-diene & 7.38 & $953 / 944$ & - & 0.1 \\
\hline 6. & sabinene & 7.92 & $969 / 965$ & 0.3 & 0.1 \\
\hline 7. & $\beta$-pinene & 8.00 & $974 / 966$ & - & 1.1 \\
\hline 8. & myrcene & 8.10 & $988 / 984$ & 0.4 & 1.1 \\
\hline 9. & $\alpha$-phellandrene & 8.98 & $1002 / 996$ & - & 1.2 \\
\hline 10. & $\delta$-3-carene & 9.15 & $1008 / 1002$ & - & 0.4 \\
\hline 11. & $\alpha$-terpinene & 9.39 & $1018 / 1008$ & - & 0.5 \\
\hline 12. & $p$-cymene & 9.59 & $1020 / 1017$ & 0.1 & 16.6 \\
\hline 13. & limonene & 9.73 & $1024 / 1020$ & 1.1 & 10.8 \\
\hline 14. & 1,8-cineole & 9.80 & $1026 / 1022$ & 0.6 & - \\
\hline 15. & $(Z)-\beta$-ocimene & 10.10 & $1032 / 1031$ & 0.6 & 1.5 \\
\hline 16. & (E)- $\beta$-ocimene & 10.40 & $1044 / 1041$ & 0.3 & 0.6 \\
\hline 17. & $y$-terpinene & 10.75 & $1054 / 1050$ & 0.1 & 1.4 \\
\hline 18. & cis-sabinene hydrate & 11.09 & $1065 / 1060$ & 0.5 & 1.3 \\
\hline 19. & camphenilone & 11.13 & $1083 / 1076$ & - & 0.1 \\
\hline 20. & terpinolene & 11.85 & $1086 / 1080$ & - & 0.1 \\
\hline 21. & linalool & 12.33 & $1095 / 1098$ & 20.3 & 1.5 \\
\hline 22. & trans-sabinene hydrate & 12.42 & $1098 / 1099$ & 0.1 & 0.4 \\
\hline 23. & cis-thujone & 12.45 & $1101 / 1101$ & - & 0.1 \\
\hline 24. & isopentyl isovalerate & 12.51 & $1102 / 1102$ & 0.3 & - \\
\hline 25. & 2-methylbutyl isovalerate & 12.68 & $1103 / 1103$ & 0.2 & - \\
\hline 26. & trans-pinene hydrate & 12.81 & $1110 / 1107$ & 0.2 & - \\
\hline 27. & (Z)-p-menth-2-en-1-ol & 12.96 & $1118 / 1115$ & 0.1 & 0.2 \\
\hline 28. & $\alpha$-campholenal & 13.08 & $1122 / 1118$ & 0.3 & 0.6 \\
\hline 29. & trans-pinocarveol & 13.17 & $1135 / 1130$ & - & 0.6 \\
\hline 30. & trans-verbenol & 13.52 & $1140 / 1139$ & 0.1 & 0.1 \\
\hline 31. & camphor & 13.65 & $1141 / 1139$ & 0.4 & 4.5 \\
\hline 32. & myrcenone & 13.83 & $1148 / 1142$ & - & $\mathrm{t}$ \\
\hline 33. & nerol oxide & 14.13 & $1154 / 1148$ & 0.3 & - \\
\hline 34. & sabina ketone & 14.28 & $1154 / 1154$ & 0.1 & - \\
\hline 35. & pinocarvone & 14.41 & 1160/1154 & - & $\mathrm{t}$ \\
\hline 36. & borneol & 14.48 & $1165 / 1160$ & 3.6 & 5.5 \\
\hline 37. & terpinene-4-ol & 14.87 & $1174 / 1170$ & 1.7 & 1.5 \\
\hline 38. & p-cymen-8-ol & 15.35 & $1183 / 1182$ & - & 0.3 \\
\hline 39. & $\alpha$-terpineol & 15.40 & $1186 / 1186$ & 3.8 & 1.1 \\
\hline 40. & cis-dihydrocarvone & 15.63 & $1193 / 1190$ & - & 0.4 \\
\hline 41. & myrtenol & 15.88 & $1194 / 1192$ & 0.2 & 0.6 \\
\hline 42. & trans-dihydrocarvone & 16.00 & $1200 / 1197$ & - & $\mathrm{t}$ \\
\hline 43. & verbenone & 16.10 & $1204 / 1202$ & - & 0.3 \\
\hline
\end{tabular}




\begin{tabular}{|c|c|c|c|c|c|}
\hline $\mathbf{N}^{0}$ & Compound $\S$ & RT & $\mathbf{K} \mathbf{I}^{\mathrm{a}} / \mathbf{K} \mathbf{b}^{\mathrm{b}}$ & $\begin{array}{c}\text { S. cuneifolia } \\
(\%)\end{array}$ & $\begin{array}{c}\text { S. montana } \\
(\%)\end{array}$ \\
\hline 44. & trans-carveole & 16.50 & $1215 / 1215$ & - & 0.6 \\
\hline 45. & isobornyl formate & 16.62 & $1223 / 1218$ & - & 0.5 \\
\hline 46. & nerol & 16.72 & $1227 / 1225$ & 2.2 & - \\
\hline 47. & hexyl-2-methyl-butanoate & 16.92 & $1233 / 1230$ & 0.2 & - \\
\hline 48. & pulegone & 17.00 & $1235 / 1230$ & 0.1 & - \\
\hline 49. & neral & 17.10 & $1235 / 1232$ & 1.2 & - \\
\hline 50. & carvacrol methyl ether & 17.21 & $1241 / 1236$ & - & 3.6 \\
\hline 51. & geraniol & 17.67 & $1249 / 1252$ & 1.4 & - \\
\hline 52. & geranial & 18.13 & $1264 / 1264$ & 0.1 & - \\
\hline 53. & bornyl acetate & 18.52 & $1287 / 1284$ & 0.1 & 0.1 \\
\hline 54. & thymol & 19.04 & $1289 / 1289$ & - & 6.5 \\
\hline 55. & carvacrol & 19.42 & $1298 / 1302$ & - & 1.1 \\
\hline 56. & cis-pinocarcyl acetat & 19.84 & $1309 / 1317$ & - & 0.1 \\
\hline 57. & myrtenyl acetate & 19.84 & $1324 / 1324$ & 0.7 & - \\
\hline 58. & $\gamma$-nonalactone & 20.03 & $1358 / 1358$ & 0.2 & - \\
\hline 59. & neoiso-dihydrocarveol acetate & 20.20 & $1358 / 1358$ & 0.1 & - \\
\hline 60. & piperitone oxide & 20.46 & $1366 / 1366$ & 0.8 & - \\
\hline 61. & linalool isobutanoate & 21.17 & $1373 / 1373$ & 1.6 & - \\
\hline 62. & $\alpha$-copaene & 21.39 & $1374 / 1373$ & 4.5 & 0.1 \\
\hline 63. & geranyl acetate & 21.67 & $1379 / 1377$ & 0.5 & - \\
\hline 64. & $\beta$-bourbonene & 21.80 & $1387 / 1374$ & 0.8 & 0.8 \\
\hline 65. & $\beta$-cubebene & 21.87 & $1387 / 1387$ & 0.5 & - \\
\hline 66. & $\beta$-elemene & 21.94 & $1389 / 1389$ & 0.5 & 0.2 \\
\hline 67. & $\beta$-longipinene & 22.43 & $1400 / 1398$ & - & 0.1 \\
\hline 68. & trans-(E)-caryophyllene & 22.75 & $1417 / 1407$ & 6.1 & 1.6 \\
\hline 69. & $\beta$-gurjunene & 23.14 & $1431 / 1414$ & - & 0.2 \\
\hline 70. & $x$-elemene & 23.32 & $1434 / 1424$ & - & $\mathrm{t}$ \\
\hline 71. & aromadendrene & 23.44 & $1439 / 1433$ & - & 0.1 \\
\hline 72. & $\alpha$-humulene & 23.81 & $1452 / 1442$ & 0.3 & 0.1 \\
\hline 73. & $\beta$-(E)-farnesene & 24.02 & $1454 / 1448$ & 0.1 & - \\
\hline 74. & cis-cadina-1(6),4-diene & 24.12 & $1461 / 1461$ & 0.2 & - \\
\hline 75. & 4,5-di-epi-aristolochene & 24.21 & $1471 / 1469$ & - & 0.1 \\
\hline 76. & $x$-muurolene & 24.53 & $1478 / 1466$ & - & 0.1 \\
\hline 77. & germacrene D & 24.68 & $1484 / 1470$ & 5.8 & 0.7 \\
\hline 78. & cis- $\beta$-guaiene & 24.03 & $1490 / 1472$ & 0.3 & - \\
\hline 79. & $x$-amorphene & 25.05 & $1495 / 1477$ & - & $\mathrm{t}$ \\
\hline 80. & bicyclogermacrene & 25.16 & $1500 / 1485$ & 2.9 & 0.4 \\
\hline 81. & $\alpha$-muurolene & 25.27 & $1500 / 1490$ & 0.5 & $\mathrm{t}$ \\
\hline 82. & $\beta$-bisabolene & 25.39 & $1505 / 1500$ & 0.5 & 0.2 \\
\hline 83. & $\alpha$-bulnesene & 25.56 & $1509 / 1509$ & 0.2 & - \\
\hline 84. & $y$-cadinene & 25.68 & $1513 / 1513$ & 1.4 & 0.2 \\
\hline 85. & $\beta$-cubebol & 25.77 & $1514 / 1514$ & 0.1 & - \\
\hline 86. & endo-1-bourbonanol & 25.86 & $1515 / 1514$ & - & $\mathrm{t}$ \\
\hline 87. & $\delta$-cadinene & 25.97 & $1522 / 1520$ & 1.1 & 0.3 \\
\hline 88. & cis-sesquisabinene hydrate & 26.63 & $1542 / 1542$ & 0.8 & - \\
\hline 89. & hedycaryol & 26.81 & $1546 / 1544$ & 0.8 & 0.7 \\
\hline
\end{tabular}




\begin{tabular}{|c|c|c|c|c|c|}
\hline $\mathbf{N}^{0}$ & Compound $\$$ & RT & $\mathbf{K} I^{\mathrm{a}} / \mathbf{K I}^{\mathrm{b}}$ & \begin{tabular}{|c|}
$\begin{array}{c}\text { S. cuneifolia } \\
(\%)\end{array}$ \\
\end{tabular} & $\begin{array}{c}\text { S. montana } \\
(\%)\end{array}$ \\
\hline 90. & germacrene B & 26.98 & $1559 / 1556$ & - & 0.4 \\
\hline 91. & nerolidol & 27.24 & $1561 / 1561$ & 5.2 & - \\
\hline 92. & 1-nor-bourbonanone & 27.17 & $1561 / 1561$ & - & $\mathrm{t}$ \\
\hline 93. & caryophyllene alcohol & 27.30 & $1570 / 1565$ & - & $\mathrm{t}$ \\
\hline 94. & germacrene D-4-ol & 27.45 & $1574 / 1567$ & - & 0.1 \\
\hline 95. & spathulenol & 27.61 & $1577 / 1567$ & 5.0 & 1.4 \\
\hline 96. & caryophyllene oxide & 27.69 & $1582 / 1571$ & 3.1 & 4.5 \\
\hline 97. & globulol & 27.99 & $1590 / 1580$ & 1.8 & - \\
\hline 98. & viridiflorol & 28.31 & $1592 / 1581$ & 0.2 & 5.4 \\
\hline 99. & ledol & 28.34 & $1602 / 1592$ & - & 0.2 \\
\hline 100. & $\beta$-oplopenone & 28.50 & $1607 / 1599$ & - & 0.5 \\
\hline 101. & humulene epoxide II & 28.50 & $1608 / 1598$ & 0.6 & - \\
\hline 102. & heliofolen-12-ol C & 28.64 & $1619 / 1617$ & - & 0.7 \\
\hline 103. & 1-epi-cubenol & 29.01 & $1622 / 1622$ & 0.3 & 0.1 \\
\hline 104. & $y$-desmol & 29.12 & $1630 / 1630$ & 0.9 & - \\
\hline 105. & epi- $\alpha$-cadinol & 29.10 & $1638 / 1631$ & 0.3 & - \\
\hline 106. & $\begin{array}{l}\text { caryophylla-4(12),8(13)- } \\
\text { dien-5 } \alpha \text {-ol }\end{array}$ & 29.41 & $1639 / 1631$ & 1.6 & 0.8 \\
\hline 107. & $T$-cadinol & 29.45 & $1640 / 1631$ & - & $\mathrm{t}$ \\
\hline 108. & $\alpha$-muurolol & 29.58 & $1645 / 1632$ & - & $\mathrm{t}$ \\
\hline 109. & $\beta$-eudesmol & 29.64 & $1649 / 1640$ & 4.5 & $t$ \\
\hline 110. & $\alpha$-eudesmol & 29.74 & $1652 / 1643$ & $\mathrm{t}$ & $t$ \\
\hline 111. & $\alpha$-cadinol & 29.80 & $1653 / 1645$ & - & $\mathrm{t}$ \\
\hline 112. & $\begin{array}{l}\text { 14-hydroxy-9-epi-(E)- } \\
\text { caryophyllene }\end{array}$ & 29.91 & $1664 / 1648$ & - & 0.5 \\
\hline 113. & 14-hydroxy-(E)-caryophyllene & 30.10 & $1666 / 1662$ & $\mathrm{t}$ & 0.1 \\
\hline 114. & $\alpha$-bisabolol & 30.28 & $1683 / 1677$ & 0.4 & - \\
\hline 115. & $\begin{array}{l}\text { germacra-4(15),5,10(14)- } \\
\text { trien-1- } \alpha \text {-ol }\end{array}$ & 30.65 & $1684 / 1678$ & 1.3 & 0.1 \\
\hline 116. & 27(14)-bisaboladien-12-ol & 30.72 & $1760 / 1755$ & - & $\mathrm{t}$ \\
\hline 117. & $\beta$-costol & 31.65 & $1765 / 1765$ & 0.2 & - \\
\hline 118. & $\alpha$-costol & 32.80 & $1773 / 1773$ & $\mathrm{t}$ & - \\
\hline \multicolumn{4}{|c|}{ The percent of the total chemical compounds } & 98.6 & 98.9 \\
\hline \multicolumn{6}{|c|}{$\begin{array}{l}\text { * } \S-\text { The minimum acceptable match factor of experimental MS spectra with } \\
\text { those from the libraries was specified to be } 80 \text { or more. } \\
{ }^{*} \mathrm{KI} \mathrm{I}^{\mathrm{a}}=\text { Kovats index, literature data; } \\
{ }^{*} \mathrm{KI} \mathrm{I}^{\mathrm{b}}=\text { Kovats index, experimentally determined; } \\
{ }^{*} \mathrm{RT}=\text { Retention time; } \\
* \% \text { Percentage of chemical compounds; } \\
{ }^{*} \mathrm{t}=\text { Chemical compounds with percentage less of } 0.05 \% ; \\
{ }^{*}-=\text { Chemical compounds which are not detected in the analysed sample. }\end{array}$} \\
\hline
\end{tabular}


COMPARATIVE STUDY OF CHEMICAL COMPOSITION OF THE ESSENTIAL OILS ...

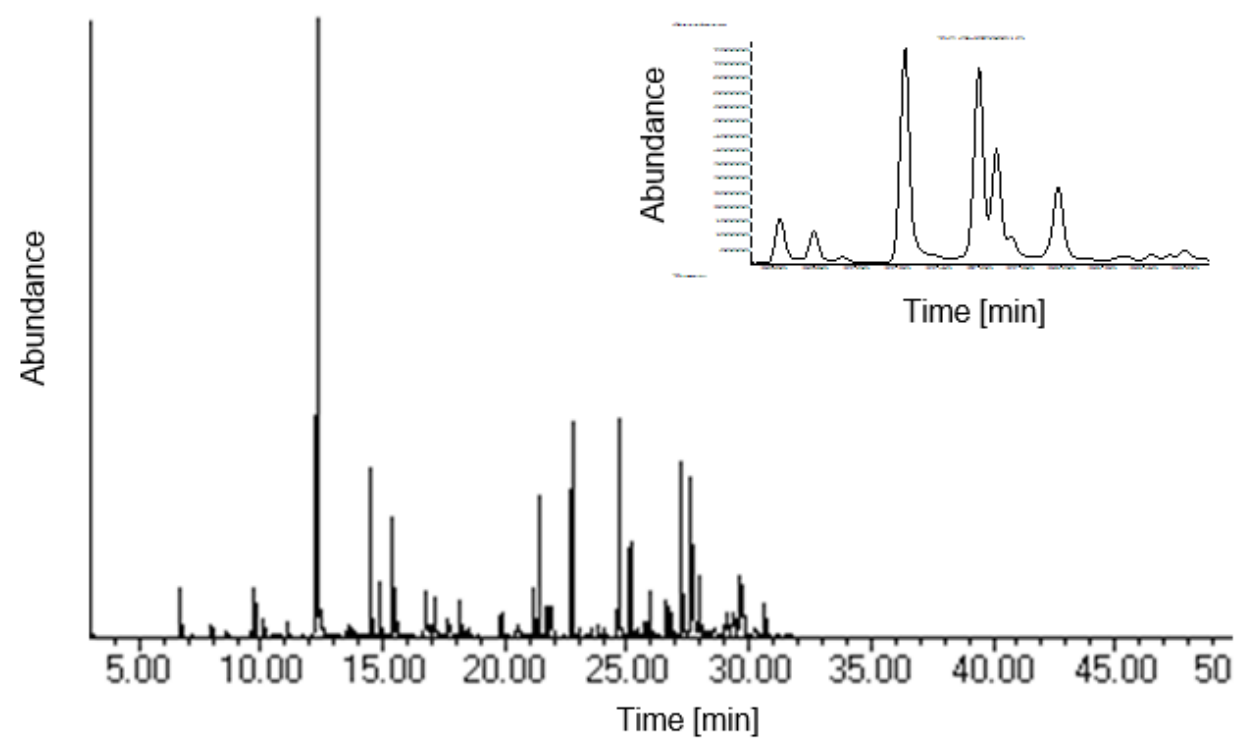

Figure 1. GC/MS chromatogram of $S$. cuneifolia essential oil

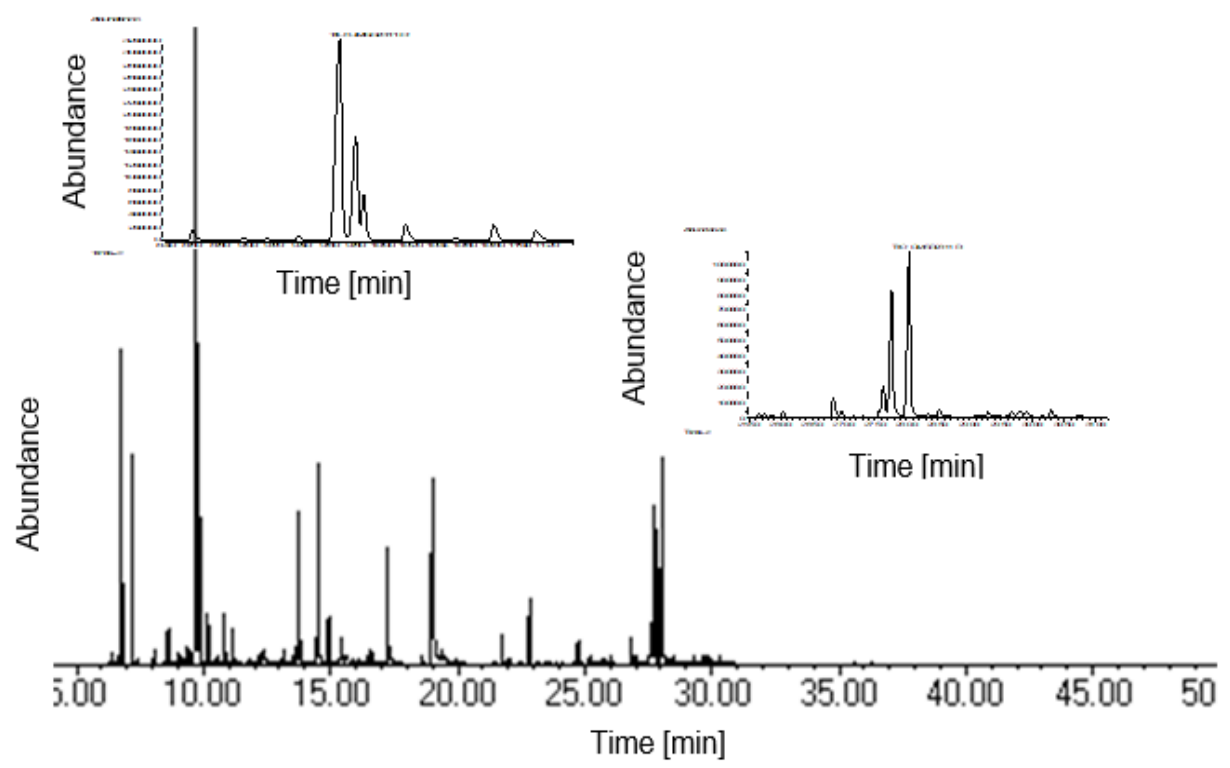

Figure 2. GC/MS chromatogram of S. montana essential oil 


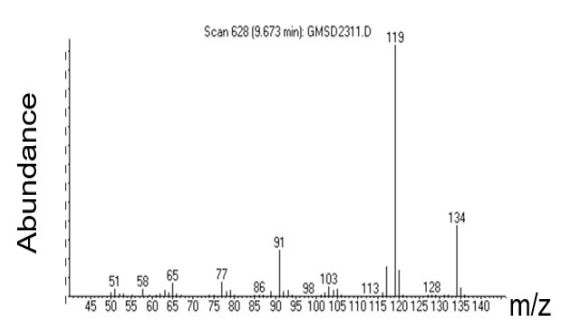

p-cymen, experimental

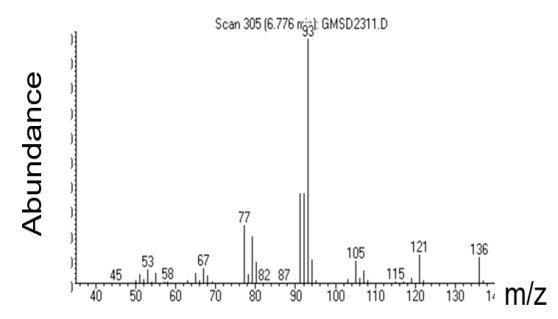

alpha-pinene, experimental

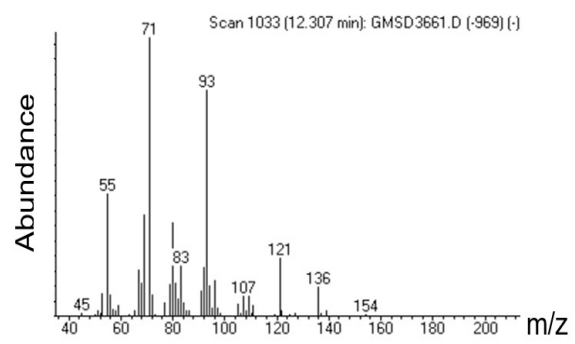

Linalool, experimental

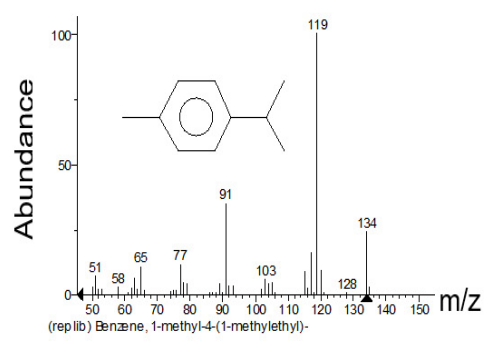

p-cymen, NIST base

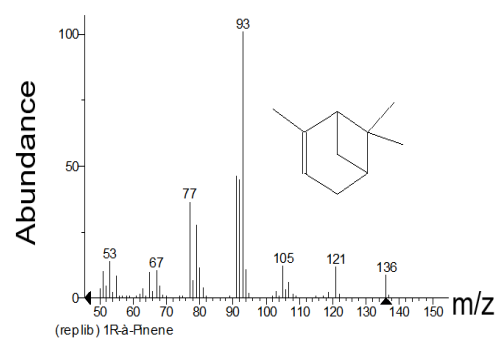

alpha-pinene, NIST base

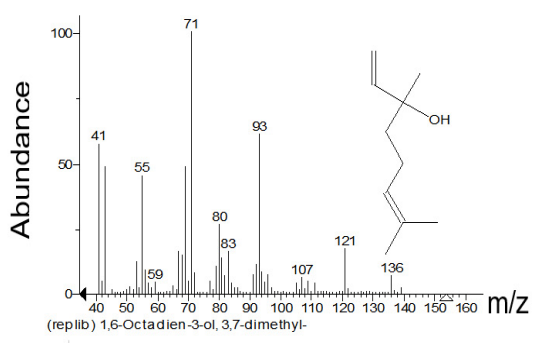

Linalool, NIST base

Figure 3. Some of MS spectra of compounds identified in both of analysed essential oils

The performed analysis of $S$. cuneifolia essential oil showed that the oxygenated monoterpenes $(41.1 \%)$ were the predominant group of compounds, with linalool as the most abundant compound representing $20.3 \%$ of the oil. Besides, $\alpha$-terpineol $(3.8 \%)$ and borneol $(3.6 \%)$ were present in relatively high concentrations. Within the sesquiterpene hydrocarbons, constituting $25.7 \%$ of the analysed sample, trans-(E)caryophyllene $(6.1 \%)$, germacrene $D(5.8 \%)$ and $\alpha$-copaene $(4.2 \%)$ were 
present in significant quantities. Oxygenated sesquiterpenes $(27.1 \%)$ were represented mostly by nerolidol $(5.2 \%)$, spathulenol $(5.0 \%)$, $\beta$-eudesmol $(4.5 \%)$ and caryophyllene oxide $(3.1 \%)$. The group of monoterpene hydrocarbons were represented with only $3.8 \%$ with limonene $(1.1 \%)$ and $\alpha$-pinene $(0.7 \%)$ as the main constituents.

Conversely, the oil of $S$. montana showed that the group of monoterpene hydrocarbons $(46.6 \%)$ were the predominant group of compounds. The most abundant compound in the group was $p$-cymene representing $16.6 \%$. Limonene $(10.8 \%)$ and $\alpha$-pinene $(6.1 \%)$ were present in a high percentage, as well. The group of oxygenated monoterpenes constituted $31.6 \%$ of the oil. Within this group thymol $(6.5 \%)$, borneol $(5.5 \%)$ and camphor $(4.5 \%)$ were determined to be in significant amounts. Oxygenated sesquiterpenes (15.2\%) and hydrocarbon sesquiterpenes (5.5\%) were present in a lower percentage in comparison to $S$. cuneifolia. Within the group of oxygenated sesquiterpenes viridiflorol $(5.4 \%)$, caryophyllene oxide $(4.5 \%)$ and spathulenol $(1.4 \%)$ were the main constituents. Furthermore, the most abundant compounds in the group of sesquiterpenes hydrocarbons were trans-(E)-caryophyllene (1.6\%) and $\beta$-bourbonene $(0.7 \%)$.

The different classes of the chemical compounds identified in the investigated essential oils were presented in Figure 4.

\section{$\%$ ๓S. cuneifolia $\backsim$ S. montana}

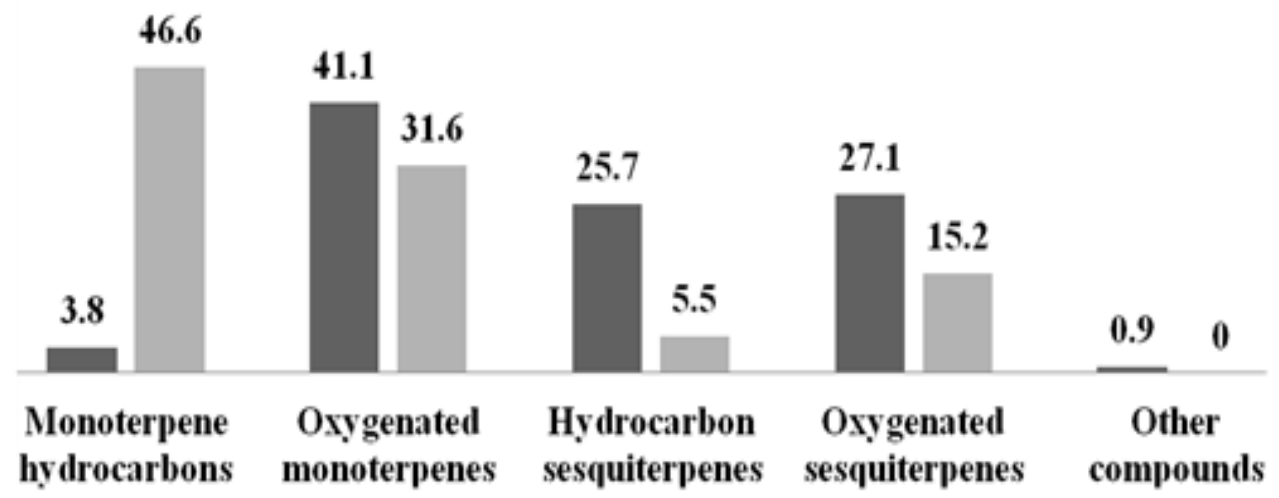

Figure 4. The comparison of the different classes of the chemical compounds of essential oils obtained from two Satureja species 
The presented data revealed the significant difference in the qualitative and quantitative composition of essential oils obtained from $S$. cuneifolia and $S$ montana. Generally, the presented chemical profiles of the essential oils and comparison to the data presented in available literature might be important in order to evaluate the quality of the investigated plant materials and their possible applications for different therapeutic purposes.

S. cuneifolia essential oil contained linalool (20.3\%), trans-(E)caryophyllene $(6.1 \%)$, germacrene D $(5.8 \%)$, nerolidol $(5.2 \%)$ and spathulenol $(5.0 \%)$ as the main constituents with the concentration greater than five percent. The oil obtained from S. montana showed that $p$-cymene $(16.6 \%)$, limonene $(10.8 \%)$, thymol $(6.5 \%)$, $\alpha$-pinene $(6.1 \%)$, borneol $(5.5 \%)$ and viridiflorol $(5.4 \%)$ were the main constituents (Table 2 ).

The search of the up to now published papers, revealed quite different chemical profile regarding the investigated essential oils. Namely, according to Bezić et al. [4], the main constituent of S. cuneifolia essential oil was carvacrol, which representing $17.7 \%$ of the oil. In addition, $y$ terpinene (14.8\%), p-cymene $(9.8 \%)$, linalool $(6.6 \%)$ and limonene $(6.2 \%)$ were present in a high percentage. Similar results were obtained for species $S$. montana, the major compounds in the essential oil were carvacrol $(13.7 \%), \quad p$-cymene $(11.8 \%), \quad \gamma$-terpinene $(10.6 \%)$, limonene $(9.5 \%)$ and borneol (5.8\%) [4]. The summary of the comparison of the main constituents determined in investigated essential oils to the literature data were presented in Table 2.

Besides Bezic et al. [4], Tommasi et al. [17] investigated the chemical composition of $S$. cuneifolia essential oil obtained from Mediterranean area, determined linalool (9.6-32.7\%), borneol (12.9$24.0 \%)$ and $\alpha$-pinene $(9.5-11.7 \%)$ to be the main constituents [17]. The essential oil of $S$. montana originating from Albania, according to $\mathrm{De}$ Oliveira et al. [18] was characterised by a high content of thymol $(28.9 \%)$, p-cymene (12.0\%), linalool (11.0\%) and carvacrol (10.7\%) [18].

Based on recently published data and results presented in this study, it is evident that a significant difference existed in the chemical composition of investigated oils. The chemical composition variability of essential oils among the two Satureja species probably could be attributed to ecological conditions, the stages of development, life cycle and/or some genetically influenced factors $[4,18]$. 
Table 2. Comparison of the main constituents (percentage more than 5) in the analysed essential oils of $S$. cuneifolia and $S$. montana to the results available in the recently published papers

\begin{tabular}{|c|c|c|c|c|c|c|c|}
\hline $\mathbf{N}^{0}$ & Compound & \begin{tabular}{|c} 
Investi \\
gated \\
sample \\
S. \\
cuneifolia
\end{tabular} & $\begin{array}{c}\text { Previous } \\
\text { studies* } \\
S \\
\text {.cuneifolia }\end{array}$ & Ref.* & \begin{tabular}{|c|} 
Investi \\
gated \\
sample \\
S. \\
montana \\
\end{tabular} & $\begin{array}{l}\text { Previous } \\
\text { studies** } \\
\text { S. montana }\end{array}$ & Ref.** \\
\hline 1. & $\alpha$-pinene & $<5 \%$ & $5.8-20.7 \%$ & 5,15 & $6.1 \%$ & $<5 \%$ & 14,15 \\
\hline 2. & $p$-cymene & $<5 \%$ & $8.7-14.8 \%$ & 4,15 & $16.6 \%$ & $6.61-12.6 \%$ & $4,5,14$ \\
\hline 3. & limonene & $<5 \%$ & $6.2-17.4 \%$ & $4,5,15$ & $10.8 \%$ & $9.5 \%$ & 4 \\
\hline 4. & $\gamma$-terpinene & $<5 \%$ & $5.6-14.8 \%$ & 4,15 & $<5 \%$ & $8.1-13.24 \%$ & 4,5 \\
\hline 5. & linalool & $20.3 \%$ & $6.6-18.2 \%$ & 4,15 & $<5 \%$ & $15.38-32.58 \%$ & 14,15 \\
\hline 6. & borneol & $<5 \%$ & $5.8-12.2 \%$ & 15 & $5.5 \%$ & $5.8-11.5 \%$ & 4,15 \\
\hline 7. & thymol & - & $<5 \%$ & $4,15,16$ & $6.5 \%$ & $5.4-24.69 \%$ & $14,15,16$ \\
\hline 8. & carvacrol & - & $5.0-17.7 \%$ & $4,15,16$ & $<5 \%$ & $15.19-63.4 \%$ & 14,16 \\
\hline 9. & $\begin{array}{l}\text { trans-(E)- } \\
\text { caryophyllene }\end{array}$ & $6.1 \%$ & $5.2-9.3 \%$ & 15 & $<5 \%$ & $<5 \%$ & 14,15 \\
\hline 10. & germacrene $\mathrm{D}$ & $5.8 \%$ & - & $4,5,15$ & $<5 \%$ & $<5 \%$ & 14 \\
\hline 11. & nerolidol & $5.2 \%$ & - & $4,5,15$ & - & $9.36 \%$ & 14 \\
\hline 12. & spathulenol & $5.0 \%$ & $5.3-13.2 \%$ & 15,16 & $<5 \%$ & $<5 \%$ & 14,15 \\
\hline 13. & viridiflorol & $<5 \%$ & $<5 \%$ & 15 & $5.4 \%$ & - & 4,15 \\
\hline
\end{tabular}

\section{CONCLUSIONS}

The presented data revealed the significant difference in the qualitative and quantitative composition of essential oils obtained from $S$. cuneifolia and S. montana. Based on applied techniques, more than 100 compounds were identified in both investigated essential oils, which made 98.6-98.9\% of the total chemical compounds. The results also showed that investigated essential oils of Satureja species have authentic terpenoid composition in comparison to other published studies. Moreover, Satureja species from different geographical origins showed different chemical profiles. Hence, chemical composition variability of essential oils among Satureja species most probably depended on the genotype of the plant, ecological conditions and the stage of plant ontogenetic development. 


\section{EXPERIMENTAL SECTION}

\section{Plant material}

The plant material was collected at the end of August 2014, at the National park Lovćen, Montenegro (Figure 5). The aerial parts of two Lamiaceae species, wild savory (Satureja cuneifolia Ten.) and winter savory (Satureja montana L.) were air-dried in a shade at room temperature and afterwards stored in paper bags in a cool and dry place. Determination of plant species was performed by Prof. Danijela Stešević and voucher specimens kept at the Department of Biology, Faculty of Natural Science and Mathematics, University of Montenegro.

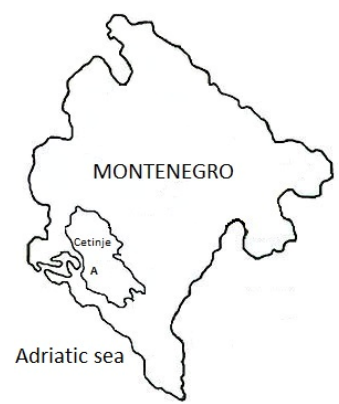

Figure 5. Map of the samples origins from National park Lovćen $(A)$ is indicated at the map of Montenegro

\section{Isolation procedure}

The dried, powdered plant material was subjected to hydrodistillation for 3 hours by using glass Clevenger type apparatus, according to the method described by the European Pharmacopoeia and by the Yugoslav Pharmacopoeia [19, 20]. The obtained essential oils were dried over anhydrous sodium sulfate $\left(\mathrm{Na}_{2} \mathrm{SO}_{4}\right)$, filtered and stored in an airtight container in a freeze until gas chromatography analyses.

\section{Chemical analysis of essential oil profiles (GC-FID and GC-MS)}

Gas chromatography (GC-FID). Gas chromatography analysis of the essential oils were carried out on an HP-5890 Series II GC apparatus [Hewlett-Packard, Waldbronn (Germany)], equipped with the split-splitless injector and automatic liquid sampler (ALS), attached to HP-5 column (25 m 
$\times 0.32 \mathrm{~mm}$ i.d. and $0.52 \mu \mathrm{m}$ film thickness) and fitted with a flame ionization detector (FID). Carrier gas was $\mathrm{H}_{2}(1 \mathrm{ml} / \mathrm{min})$, with a split ratio of $1: 30$, injector temperature was $250^{\circ} \mathrm{C}$, detector temperature $300^{\circ} \mathrm{C}$, while column temperature was linearly programmed from 40 to $260^{\circ} \mathrm{C}$ with a rate of change of the $4^{\circ} \mathrm{C} / \mathrm{min}$, and then kept isothermally at $260^{\circ} \mathrm{C}$ for $10 \mathrm{~min}$. Solutions of essential oil in alcohol $(10 \mathrm{mg} / \mathrm{ml})$ were consecutively injected in an amount of $1 \mu \mathrm{l}$. Area percent reports, obtained as result of standard processing of chromatograms, were used as a base for the quantification analysis.

Gas chromatography I mass spectrometry (GC-MS). The same analytical conditions as those mentioned for GC-FID were employed for GC/MS analysis, along with column HP-5MS $(30 \mathrm{~m} \times 0.25 \mathrm{~mm}$ i.d. and 0.25 $\mu \mathrm{m}$ film thickness), using HP G $1800 \mathrm{C}$ Series II GCD system [HewlettPackard, Palo Alto, CA (USA)]. As the carrier gas used helium. The transfer line was heated to $260^{\circ} \mathrm{C}$. The mass spectra were obtained in $\mathrm{El}$ mode, with an ionisation voltage of 70 electron volt $(\mathrm{eV})$; in the range from 40 to $450 \mathrm{~m} / \mathrm{z}$. The amount of the injected sample, dissolved in alcohol $(10 \mathrm{mg} / \mathrm{ml})$ was $0.2 \mu \mathrm{l}$. The components of the essential oil were identified by comparison of their mass spectra to those from Wiley 275 and NIST/NBS (NIST-National Institute of Standards and Technology / NBS-National Bureau of Standards) libraries, using different search engines. Identification of the compounds was achieved by comparing their Kovats' retention indices and mass spectra with those reported in the literature [21] and supplemented by the Automated Mass Spectral Deconvolution and Identification System software (AMDIS ver. 2.1), GC-MS library [22]. The experimental values for Kovats' retention indices were determined by the use of calibrated Automated Mass Spectral Deconvolution and Identification System Software (AMDIS ver. 2.1), GCMS library [22], and also compared to those from available literature (Adams 2007) [21] and used as additional tool to approve MS findings. The relative proportion of the essential oil constituents were expressed as percentages obtained by peak area normalisation, all the relative response factors were entered as one.

\section{ACKNOWLEDGMENTS}

The authors are very grateful to the Ministry of Education, Science and Technological Development of the Republic of Serbia for the financial support of Grant No. III-45107. Authors would like to thank Prof. Danijela Stešević for determination of plant species in this research. 


\section{REFERENCES}

1. A. M. El-Hagrassi, W. E. Abdallah, A. F. Osman, K. A. Abdelshafeek, Asian Journal of Pharmaceutical and Clinical Research, 2018, 11, 142.

2. A. Namayandeh, N. Mokhtari, M. M. Kamelmanesh, M. T. Bedaf, Journal of Genetics, 2017, 96, e5.

3. F. Jafari, F. Ghavidel, M. M. Zarshenas, Journal of Acupuncture and Meridian Studies, 2016, 9, 118.

4. N. Bezić, I. Samanić, V. Dunkić, V. Besendorfer, J. Puizina, Molecules, 2009, $14,925$.

5. M. Skočibušić, N. Bezić, Phytotherapy Research, 2004, 18, 967.

6. D. Azaz, F. Demirci, F. Satil, M. Kürkçüoğlu, K. Başer, Zeitschrift für Naturforschung. C, Journal of biosciences, 2002, 57, 817.

7. I. Sadeghi, M. Yousefzadi, M. Behmanesh, M. Sharifi, A. Moradi, Iranian Red Crescent medical journal, 2013, 15, 70.

8. K. Yamasaki, M. Nakano, T. Kawahata, H. Mori, T. Otake, N. Ueba, I. Oishi, R. Inami, M. Yamane, M. Nakamura, H. Murata, T. Nakanishi, Biological and pharmaceutical bulletin, 1998, 21, 829.

9. T. Dodoš, J. Aleksić, N. Rajčević, P. D. Marin, Archives of Biological Sciences, 2014, 66, 285.

10.J. Vladić, O. Canli, B. Pavlić, Z. Zeković, S. Vidović, M. Kaplan, The Journal of Supercritical fluids, 2017, 120, 86.

11.Y. Kan, U. S. Uçan, M. Kartal, M. L. Altun, S. Aslan, E. Sayar, T. Ceyhan, Turkish Journal of Chemistry, 2006, 30, 253.

12.F. Oke, B. Aslim, S. Ozturk, S. Altundag, Food Chemistry, 2009, 112, 874.

13.A. Capuzzo, M. E. Maffei, A. Occhipinti, Molecules, 2013, 18, 7194.

14.T. Mihajilov-Krstev, D. Radnović, D. Kitić, V. Stankov-Jovanović, V. Mitić, Z. Stojanović-Radić, B. Zlatković, Central European journal of biology, 2014, 9, 668.

15. M. Milos, A. Radonic, N. Bezic, V. Dunkic, Flavour and fragrance journal, 2001, 16, 157.

16.S. Ćavar, M. E. Šolić, M. Maksimović, Botanica serbica, 2013, 37, 159.

17.L. C. Negro, A. Miceli, F. Mazzotta, The Journal of essential oil research : JEOR, 2009, 21, 185.

18.T. L. C. De Oliveira, R. De Araújo Soares, E. M. Ramos, M. Das Graças Cardoso, E. Alves, R. H. Piccoli, International journal of food microbiology, 2011, 144, 546.

19. European Pharmacopoeia 6.0., Vol. 1, Council of Europe, Strasbourg Cedex 2007.

20. Yugoslavian Pharmacopoeia IV, Pharmacopoea Jugoslavica editio quarta, Ph. Jug. IV, Vol. I. National Institute for Health Protection, Belgrade, 1984.

21.R. P. Adams, Identification of Essential Oil Components by Gas Chromatography I Mass Spectrometry, 4th Ed., Allured Publishing Corporation: Carol Stream, Illinois, 2007.

22. Automated Mass Spectral Deconvolution and Identification System software (AMDIS ver. 2.1), National Institute of Standards and Technology (NIST), Standard Reference Data Program, Gaithersburg, MD, 2005. 